\title{
The Implementation of Integrated Management of Children IIIness in Primary Health Community in Yogyakarta, Indonesia
}

\author{
Rahmah Rahmah1*, Yoni Astuti ${ }^{2}$ \\ ${ }^{1}$ Department of Pediatrics Nursing, School of Nursing Medicine and Health Science, University Muhammadiyah of Yogyakarta, \\ Bantul, Indonesia; ${ }^{2}$ Department of Biochemistry, Faculty of Medicine and Health Sciences, Universitas Muhammadiyah \\ Yogyakarta, Yogyakarta, Indonesia
}

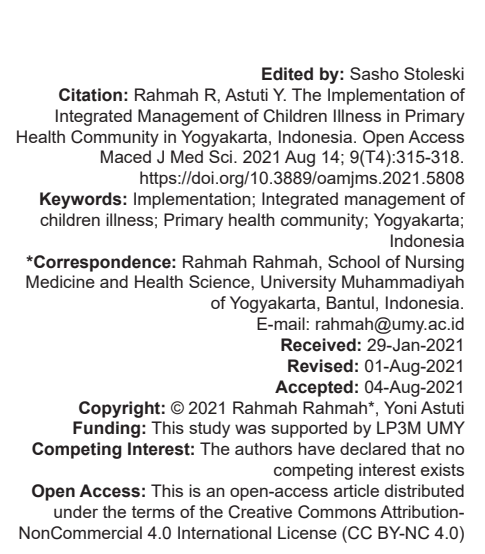

Abstract

BACKGROUND: The mortality rate for infants and toddlers aged 12-59 months in Yogyakarta has shown a fluctuating trend between 2008 and 2014. To reduce infant and toddler mortality rates, the Yogyakarta city government has made some efforts to implement integrated management of children illness (IMCl). Thus, it can be said that one of the successful actions of the government in reducing mortality and morbidity of infants and toddlers is determined by optimizing the role of $\mathrm{IMCl}$ in the primary health community $(\mathrm{PHC})$ as the vanguard in public health services. The results of the preliminary study found that all PHCs in the cities of Bantul and Yogyakarta had implemented IMCI, although there were no data related to how the inputs, processes, and outputs in the implementation of the IMCI were.

AIM: This study aims to determine the implementation of IMCI related to its inputs, processes, and outputs at PHC in Bantul and Yogyakarta City.

METHODS: This research method used descriptive research.

RESULTS: Based on previous study results, in 2019, the average health center had fulfilled the "output" activities regarding $60 \%$ of toddler visits carrying out $\mathrm{IMCl}$.

CONCLUSION: It indicated that some health centers had implemented the IMCI program optimally.

\section{Introduction}

The infant mortality rate in Bantul has shown a fluctuating trend between 2012 and 2017. Based on the data obtained from Bantul's health profile in 2018, the year 2017 saw a rise of birth, accounting for $8.47 / 1000$ births of living rise compared to 2016 with 7.65/1000 live births (Health Profile of Bantul Regency, 2018). The cases of infant mortality in Bantul Regency in 2017 reached 108 cases, with the highest infant mortality occurring in PHC Jetis II and Sedayu II area. Furthermore, infant mortality caused by low birth weight reached 22 cases, while the mortality due to congenital abnormalities reached 20 cases. On the other hand, the mortality cases of under-5-year-old children's deaths in 2017 reached 115 people, with the largest number's deaths in PHC Jetis 2, which reached 10 people [1].

Sustainable development goals (SDGs) or objective development of sustainable are often referred to as the agenda of development of global scope, which is more extensive than the Millennium Development Goals or Objectives Development of the Millennium ended in 2015. SDGs aim to ensure a healthy life and improve well-being for all populations of all ages by improving reproductive, maternal, and child health; ending or stopping the epidemic of major infectious diseases; reducing the disease which is not contagious and are caused by the environment; achieving universal health coverage; and ensuring access to drugs and vaccines are safe, affordable, and effective for all [2].

According to the World Health Organization in 2005, integrated management of children illness (IMCl) is an integrated approach to children's health that focuses on all children's welfare. IMCl aims to reduce death, disease, and disability and improve the growth and development that is good for under 5-yearold children. IMCI includes elements of preventive and curative carried out by the family and society as well as by the health facilitators.

The government, especially the Ministry of the Health Republic of Indonesia, has continued improving the quality and scope of service $\mathrm{IMCl}$ improvement in the health center with various kinds of strategies that lead to the improvement of the quality human resources, improvement of management services, and the evaluation of the health service with the $I \mathrm{MCl}$ approach. In fact, there is a difference in the quality and scope of $\mathrm{IMCl}$ in every health center in each region. 
The previous study from the department of health of Bantul and Yogyakarta showed that all of the health centers in Bantul and Yogyakarta had implemented the IMCl program, but the input, process, and output activities had not yet been completed. It brings us to find out more about implementing the $\mathrm{IMCl}$ in Bantul and Yogyakarta health centers.

\section{Methods}

This research was conducted from December 2018 until May 2019. It was descriptive research that aimed to determine the implementation of IMCI Health Center in Yogyakarta and Bantul, which involved seven health centers in Yogyakarta and seven health centers Bantul selected randomly. This study had ethical clearance from Health and Medicine Faculty University Muhammadiyah of Yogyakarta with number 067/ EC-KEPK FKIK UMY/III/2019.

The data collection used structured sheets/ notes and observation sheets divided into three sections, namely, "input," "process," and "output" activities data of IMCl implementation in each health center. In fulfilling the sheet/notes, we inquired it directly into the responsible officer for the $1 \mathrm{MCl}$ program while for the retrieval of "process" data, we used an observation sheet to observe the caring process at the health center 5 times, which consisted of assessment and classification using $\mathrm{IMCl}$ form; treatment measuring based on $\mathrm{IMCl}$ assessment and classification; counseling; and referral or follow-up assessment. We took the $\mathrm{IMCl}$ visit service report documentation in each health center every month to capture the "output" data. The data were analyzed by univariate analysis using a computer, and the tabulation was derived based on the number of frequency and percentage.

Table 1: The public health community list which becomes the research's subject

\begin{tabular}{ll}
\hline Yogyakarta City & Bantul \\
\hline Ngampilan & Kasihan I \\
Jetis & Sewon II \\
Gondokusuman II & Jetis I \\
Umbulharjo I & Pandak I \\
Kotagede II & Banguntapan II \\
Danurejan II & Imogiri 1 \\
Pakualaman & Kretek \\
\hline
\end{tabular}

\section{Results}

The resources were the major factor in program implementation. If the resources are less or not appropriate, the program cannot run effectively [3].

The human resources support, then, is necessary to support the implementation of qualified
$\mathrm{IMCl}$ in $\mathrm{PHC}$. To gain the qualified human resources, the human resources officers should receive training intending to build the professional officers in doing the $\mathrm{IMCl}$ health center service [4]. The training of $\mathrm{IMCl}$ of IMCl's officers will provide them information about serving sick infants. In this training, each of the officers will get cognitive and psychomotor knowledge. In addition, to complete the program, it is necessary for the program developer to gain the financial support to carry out the health service effort, which aims at operational funds, facilities, infrastructure, and the $\mathrm{IMCl}$ training program [4], [5].

Table 2: The input distribution (for human resources and funding) of the IMCI service in primary health community (PHC) of Yogyakarta city $(n=7)$ and Bantul $(n=7)$

\begin{tabular}{|c|c|c|c|c|}
\hline \multirow[t]{3}{*}{ Input } & \multicolumn{2}{|c|}{ Yogyakarta city } & \multicolumn{2}{|l|}{ Bantul } \\
\hline & \multicolumn{2}{|c|}{ Percentage } & \multicolumn{2}{|c|}{ Percentage } \\
\hline & Available & Not available & Available & Not available \\
\hline IMCI team leaders & 85.7 & 14.3 & 42.9 & 57.1 \\
\hline $\mathrm{IMCl}$ officers & 100 & 0 & 100 & 0 \\
\hline $\mathrm{IMCl}$ training & 85.7 & 14.3 & 71.4 & 28.6 \\
\hline $\mathrm{IMCl}$ funding & 0 & 100 & 14.3 & 85.7 \\
\hline
\end{tabular}

Subsequently, the IMCI training aims to teach the health service human resources such as nurses, midwives, doctors, nutritionists, and other health service officers about the management process in handling sick infants. IMCI training can also improve the officers' knowledge and skills, primarily to assess and classify the infants' and toddlers' disease [4], [5].

Many health centers stated that the number of health officers, which consisted of general practitioners and nurses, especially in the $\mathrm{IMCl}$ section, still lacked as there was a disparity in the number of patients and the trained officers. In addition, the implementation of the IMCl should take into account a whole-body condition checking. It means that the IMCI implementation should be supported by the trained officers and the leadership capability of the IMCl's head program [6].

Furthermore, to complete the program, funding supports are needed. However, the $I \mathrm{MCl}$ implementation in each $\mathrm{PHC}$ in Yogyakarta has not been supported by the department of health of Yogyakarta as every health center currently running the $\mathrm{IMCl}$ program was expected to find their funding supports themselves. According to this case, Muninjaya stated that operational funds should support the staff's program activities. These funds could be allocated for the cost of field visits, maintenance, and equipment purchase to support the program activities. The lack of support from the department of health of Yogyakarta then becomes one of the factors of funding crisis of $\mathrm{IMCl}$ program in every health center, which leads to the obstacle of the implementation of IMCI [7].

Based on the results of the study, it could be seen that almost PHC had the watch for calculating the heart rate and scales for babies. Meanwhile, there were only two health centers which had spoons glasses to place boiled water (oral rehydration therapy corners) since the availability of places, while the infusion sets, 
needles, and syringes, gauze, pipe stomach, and tool suction lenders were mostly not available in the IMCl's room. Rather, it was at the IGD (emergency room). Furthermore, the tool grinding drugs were only available in the pharmacy room. This lack of infrastructure then led the IMCl's program to run in not optimal progress [8].

Table 3: The input distribution (for facilities) of IMCl service in the primary health centers of Yogyakarta $(n=7)$ and Bantul $(n=7)$

\begin{tabular}{|c|c|c|c|c|}
\hline \multirow[t]{3}{*}{ Input } & \multirow{2}{*}{\multicolumn{2}{|c|}{$\frac{\text { Yogyakarta }}{\text { Percentage }}$}} & \multirow{2}{*}{\multicolumn{2}{|c|}{$\begin{array}{l}\text { Bantul } \\
\text { Percentage }\end{array}$}} \\
\hline & & & & \\
\hline & Available & Not available & Available & Not available \\
\hline $\begin{array}{l}\text { The watch for calculating the } \\
\text { heart rate }\end{array}$ & 100 & 0 & 85.7 & 14.3 \\
\hline Tensimeter and child cuffs & 57.1 & 42.9 & 85.7 & 14.3 \\
\hline $\begin{array}{l}\text { Spoon, glass, and teapot for boiled } \\
\text { water (used in ORS corner) }\end{array}$ & 28.6 & 71.4 & 28.6 & 71.4 \\
\hline $\begin{array}{l}\text { Infuse set with wing needles } \\
\text { number } 23 \text { and } 25\end{array}$ & 42.9 & 57.1 & 71.4 & 28.6 \\
\hline $\begin{array}{l}\text { Syringe and syringe needle size } 1 \\
\mathrm{ml} ; 2.5 \mathrm{ml} ; 10 \mathrm{ml}\end{array}$ & 57.1 & 42.9 & 100 & 0 \\
\hline Babies scale & 100 & 0 & 100 & 0 \\
\hline Thermometer & 100 & 0 & 100 & 0 \\
\hline Gauze or cotton & 42.9 & 57.1 & 100 & 0 \\
\hline Gastric pipe & 30 & 70 & 28.6 & 71.4 \\
\hline Pounding drugs stuffs & 42.9 & 57.1 & 71.4 & 28.6 \\
\hline Sucking lenders stuffs & 28.6 & 71.4 & 42.9 & 57.1 \\
\hline
\end{tabular}

Subsequently, other problems encountered on the IMCl's infrastructure fulfillment were the lack of adequate space for the IMCl's implementation. It was because the $\mathrm{IMCl}$ program, during its implementation, had joined the KIA room and general section. Furthermore, the IMCI service was frequently hampered by the infrastructure's unavailability [4].

Moreover, the research showed that seven health centers had already been met with the equipment needed for $\mathrm{IMCl}$, which was based on $\mathrm{IMCl}$ module 7 guidelines. However, some tools were not available in many health centers, such as spoons, cups, and teapots, to place boiled water (used in oral rehydration therapy corners). There were only two health centers $(28.6 \%)$ that had the complete equipment.

Table 4: The results of evaluation of IMCI service process in the health centers of Yogyakarta $(n=7)$

\begin{tabular}{lllll}
\hline Community health center & Percentage & & \\
\cline { 2 - 5 } & 1 & 2 & 20 & 4 \\
\hline Danurejan II & 100 & 100 & 60 & 0 \\
Gondokusuman II & 100 & 100 & 100 & 40 \\
Jetis & 100 & 100 & 40 & 0 \\
Kotagede II & 100 & 100 & 100 & 60 \\
Ngampilan & 100 & 100 & 100 & 0 \\
Pakualaman & 100 & 100 & 40 & 0 \\
Umbulharjo I & 100 & 100 & 65.7 & 14.2 \\
Mean & 100 & 100 & &
\end{tabular}

The oral rehydration therapy corner should be available in the health center, especially in the waiting room, as it could be used as the observation center for diarrhea sufferers. The ORS corner was expected to increase the society and the officers' trust for the diarrhea patients' prosecution, especially by oral rehydration [8], [9].

The health center could provide a particular room that could be used as an active rehydration oral corner. The officers could promote oral rehydration to the mothers and the patient's family. When doing promotions, the officers could also explain how to prepare oral rehydration and sufficient consumption for the patients [8], [9].

\section{Information}

1. Assessment and classification using the $\mathrm{IMCl}$ form

2. Treatment measures based on the assessment and classification of $\mathrm{IMCl}$

Table 5: The results of evaluation of $I \mathrm{MCl}$ service process in the PHC of Bantul $(n=7)$

\begin{tabular}{llll}
\hline Yogyakarta & $\%$ & Bantul & $\%$ \\
\hline Ngampilan & 40 & Kasihan I & 85,3 \\
Jetis & 84.8 & Sewon II & 65.6 \\
Gondokusuman 2 & 69 & Jetis I & 91.1 \\
Umbulharjo 1 & 66.5 & Pandak I & 96 \\
Kotagede 2 & 61.4 & Banguntapan II & 99 \\
Danurejan 2 & 80 & Imogiri I & 90.7 \\
Pakualaman & 55 & Kretek & 93 \\
Mean & 65.2 & & 88.7 \\
\hline Source: Primary data, 2019, IMCl: Integrated management of children illness, PHC: Primary health \\
community.
\end{tabular}

3. Counseling

4. Referral or follow-up assessment.

Furthermore, based on the results of this study, most of the health centers had not implemented the program gradually. Many of them still used conventional methods that eventually did not address the age levels when handling sick infants. The officers also stated that $I \mathrm{MCl}$ had not been fulfilled entirely due to the lack of human resources to finish this stage, making them not comply with the $I \mathrm{MCl}$ procedures [10].

Table 6: The mean of IMCI service output per month in PHC Yogyakarta $(n=7)$ and Bantul $(n=7)$

\begin{tabular}{lllll}
\hline Community health center & 1 & 2 & 3 & 4 \\
\hline $\begin{array}{l}\text { Kasihan I } \\
\text { Yes }\end{array}$ & 100.0 & 100.0 & 0.0 & 0.0 \\
$\quad$ No & 0.0 & 0.0 & 100.0 & 100.0 \\
$\begin{array}{l}\text { Sewon II } \\
\text { Yes }\end{array}$ & 100.0 & 100.0 & 0.0 & 0.0 \\
$\quad$ No & 0.0 & 0.0 & 100.0 & 100.0 \\
Jetis I & 100.0 & 100.0 & 40.0 & 0.0 \\
$\quad$ Yes & 0.0 & 0.0 & 60.0 & 100.0 \\
$\quad$ No & & & & \\
Pandak I & 60.0 & 60.0 & 60.0 & 40.0 \\
$\quad$ Yes & 40.0 & 40.0 & 40.0 & 60.0 \\
$\quad$ No & 100.0 & 100.0 & 80.0 & 20.0 \\
$\begin{array}{l}\text { Banguntapan II } \\
\text { Yes }\end{array}$ & 0.0 & 0.0 & 20.0 & 80.0 \\
$\quad$ No & & & & \\
Imogiri I & 0.0 & 0.0 & 0.0 & 0.0 \\
$\quad$ Yes & 100.0 & 100.0 & 100.0 & 100.0 \\
$\quad$ No & 100.0 & 100.0 & 0.0 & 0.0 \\
Kretek & 0.0 & 0.0 & 100.0 & 100.0 \\
$\quad$ Yes & & & & \\
$\quad$ No & & &
\end{tabular}

community.

\section{Discussion}

This research, subsequently, also showed that some health centers in Yogyakarta had been carrying out a program of $\mathrm{IMCl}$ based on $\mathrm{IMCl}$ module 7. However, PHC had not been carrying out a program of $\mathrm{IMCl}$ coherently with those guidelines. On the IMCI process, many programs should be passed, including assessment and classification using the $\mathrm{IMCl}$ form, decisive action treatment based on assessment and classification of $\mathrm{IMCl}$, counseling stage based on $\mathrm{IMCl}$ 
procedure, and referral or assessment following the plan of treatment in IMCI [9], [10].

The implementation of the referral, which did not go perfectly, could occur by several possibilities such as the lack of human resource availability [3] and the infrastructure for the prosecution of sick infants/toddlers [4], [11].

Moreover, based on the previous study results, in 2019, the average health center had fulfilled the "output" activities regarding $60 \%$ of toddler visits carrying out IMCl. It indicated that some health centers had implemented the $\mathrm{IMCl}$ program optimally.

\section{Conclusion}

In general, $100 \%$ of the health centers had had IMCl officers. However, almost $100 \%$ of the health center did not have funds allocated for $\mathrm{IMCl}$ implementation. Moreover, some health centers had fulfilled the facilities and infrastructure related to $I \mathrm{MCl}$, although they had not been implemented optimally. In addition to that case, IMCI implementation and follow-up stages did not cater to the patient's needs during the examination. In terms of the $\mathrm{IMCl}$ output activities, based on the records, many of $\mathrm{PHC}$ had performed $\mathrm{IMCl}$ services to more than $60 \%$ under-5year-old children who came to them. The research then suggests that the implementation of $\mathrm{IMCl}$ does not require funds allocation. However, the budget is still needed by the department of health of Bantul and Yogyakarta to conduct supervision activities and IMCI officers training due to the limited human resources who have already passed $\mathrm{IMCl}$ training.

\section{Acknowledgments}

We would like to express our sincere gratitude to Prilantita Diani and Tiara Ariwibowo as our students who helped us collect data and are also grateful to LP3M UMY for funding this research.

\section{References}

1. Profil Kesehatan Kabupaten Bantul, Bantul; 2018

2. Kementerian Perencanaan Pembangunan Nasional. Laporan Baseline SDG tentang Anak-Anak di Indonesia. Kementerian Perencanaan Pembangunan Nasional; 2017. https://doi. org/10.36574/jpp.v4i2.112

3. Firdaus $\mathrm{N}$, Implementation of an integrated management program for sick toddlers (MTBS) at the Pasuruan District Health Center. 2013;1:1-7. https://doi.org/10.14710/jmki.6.2.2018.114-120

4. Zainuri A. Factors that influence the non-implementation of the Integrated Management of Sick Toddlers (MTBS) at the Sentani Health Center, Jayapura Regency. 2014;3(3):1-9. https://doi. org/10.35568/healthcare.v2i1.520

5. Rohayati D. Factor analysis of the implementation of the integrated management of sick toddlers (MTBS) in the puskesmas. 2015;11(1):112-7. https://doi.org/10.35568/ healthcare.v2i1.520

6. Indarwati F, Rahmah, Panggita B, Indrawan S. Perspektif Perawat Tentang Manejemen Terpadu Balita Sakit di Puskesmas Wilayah Kabupaten Bantul Yogyakarta; 2017. https://doi. org/10.32584/jpi.v4i2.812

7. Adining Tyas Ambika Wardani. Analisis Penerapan Manajemen Terpadu Balita Sakit (Mtbs) Terhadap Kejadian Pneumonia Balita Di Puskesmas Halmahera Kota Semarang; 2016. https:// doi.org/10.35568/healthcare.v2i1.520

8. Mu'is A, Ismanto AY, Onibala F. Hubungan penerapan manajemen terpadu balita sakit (Mtbs) diare dengan kesembuhan diare pada balita di puskesmas bahu kota manado. J Keperawatan. 2014;2(2). https://doi.org/10.35907/jksbg.v9i2.42

9. Suparmi, et al. Integrated Management of Childhood Illness (IMCI) Services at Health Center in Eastern Region of Indonesia; 2018. Available from: https://www.ejournal2.litbang.kemkes. go.id. [Last accessed on2021 Jan 10].

10. Husni AD, Ansar J. Gambaran Pelaksanaan Manajemen Terpadu Balita Sakit (MTBS) Umur 2 Bulan- 5 Tahun Puskesmas Di Kota Makassar Tahun; 2012. p. 1-14. https://doi.org/10.35568/ healthcare.v2i1.520

11. Rivan GB. The relationship between the behavior of health workers and the quality of health services at the Mopuya Public Health Center, North Domuga District, Bolaang Mongondow Regency. J Ilmiah Farm. 2016;5(1):303-8. https://doi. org/10.33085/jkg.v2i3.4436 